\title{
Corrosion behavior of construction materials for ionic liquid hydrogen compressor
}

Arjomand Kermani, Nasrin; Petrushina, Irina; Nikiforov, Aleksey Valerievich; Jensen, Jens Oluf; Rokni, Masoud

Published in:

International Journal of Hydrogen Energy

Link to article, DOI:

10.1016/.ijhydene.2016.06.221

Publication date:

2016

Document Version

Peer reviewed version

Link back to DTU Orbit

Citation $(A P A)$ :

Arjomand Kermani, N., Petrushina, I., Nikiforov, A. V., Jensen, J. O., \& Rokni, M. (2016). Corrosion behavior of construction materials for ionic liquid hydrogen compressor. International Journal of Hydrogen Energy, 41(38), 16688-16695. https://doi.org/10.1016/j.ijhydene.2016.06.221

\section{General rights}

Copyright and moral rights for the publications made accessible in the public portal are retained by the authors and/or other copyright owners and it is a condition of accessing publications that users recognise and abide by the legal requirements associated with these rights.

- Users may download and print one copy of any publication from the public portal for the purpose of private study or research.

- You may not further distribute the material or use it for any profit-making activity or commercial gain

- You may freely distribute the URL identifying the publication in the public portal 


\title{
Corrosion Behavior of Construction Materials for Ionic Liquid Hydrogen Compressor
}

\author{
Nasrin Arjomand Kermani ${ }^{a}$, Irina Petrushina*b, Aleksey Nikiforov ${ }^{b}$, Jens Oluf Jensen ${ }^{b}$, Masoud \\ Rokni $^{a}$ \\ ${ }^{a}$ Thermal Energy Section, Department of Mechanical Engineering, Technical University of Denmark, Nils \\ Koppels Allé , Building 403, DK-2800 Kgs. Lyngby, Denmark \\ ${ }^{\mathrm{b}}$ Section for Proton Conductors, Department of Energy Conversion and Storage, Technical University of \\ Denmark, Kemitorvet 207, DK-2800 Kgs. Lyngby, Denmark \\ *Correspondence should be addressed to: Irina Petrushina \\ Tel:+45 45252302 , E-mail: irpe@dtu.dk
}

\begin{abstract}
The corrosion behavior of various commercially available stainless steels and nickel-based alloys as possible construction materials for components which are in direct contact with one of five different ionic liquids was evaluated. The ionic liquids, namely: 1-ethyl-3-methylimidazolium triflate, 1-ethyl-3methylimidazolium bis (trifluoromethylsulfonyl) imide, trihexyltetradecylphosphonium bis (trifluoromethylsulfonyl) imide, butyltrimethylammonium bis (trifluoromethylsulfonyl) imide, methyltrioctylammonium bis (trifluoromethylsulfonyl) imide have been identified, as performance fluids in an ionic liquid hydrogen compressor. An electrochemical cell was specially designed, and steady-state cyclic voltammetry was used to measure the corrosion resistance of the alloys in the ionic liquids at $23^{\circ} \mathrm{C}$, under atmospheric pressure.

The results showed a very high corrosion resistance and high stability for all the alloys tested. The two stainless steels, AISI 316L and AISI 347 showed higher corrosion resistance compared to AISI 321 in all the ionic liquids tested. It was observed that small addition of molybdenum, tantalum, and niobium to the alloys increased the corrosion stability in the ionic liquids studied. Hastelloy ${ }^{\circledR} \mathrm{C}-276$ showed the poorest corrosion resistance in all the ionic liquids tested. AISI 316L with high corrosion resistance and the lowest cost is recommended as the most attractive construction material for all the components, in an ionic liquid hydrogen compressor, which are in direct contact with ionic liquids used in this study.

Keywords: Ionic liquid compressor, hydrogen, Ionic liquids, Corrosion resistance, Polarization
\end{abstract}




\section{Introduction}

Ionic liquids are molten salts with melting points below $100^{\circ} \mathrm{C}$. They are composed of organic cations with organic or inorganic anions. Ionic liquids are characterized by a unique set of properties incorporating wide electrochemical potential windows, good thermal stability, negligible vapor pressure which are not achievable with any other class of materials [1,2]. Such outstanding chemical and physical properties open doors for more new and innovative applications of ionic liquids in the future.

Ionic liquids have been widely applied as alternative solvents in chemical processes [3]. Due to the possibility of designing a suitable ionic liquid with the specific physicochemical properties by selecting appropriate anion and cation combinations [4], the ionic liquids have found a wide range of industrial applications over the past decades [3-9].

Recently, the unique combination of being liquid and showing negligible vapor pressure together with good lubrication properties, high temperature stability, low compressibility and low solubility of gasses has attracted the attention of many scientists and engineers for utilizing ionic liquids in pump and compressor applications [10].

Due to good lubrication capabilities, combined with chemical stability ionic liquids could be conveniently used as a promising alternative for lubrication oil in pumps and compressors. This option will likely reduce significantly mechanical losses and consequently improve efficiency in hydraulic and pneumatic applications [10]. Properties such as low vapor pressure combined with low gas solubility make ionic liquids a promising option for lubrication in liquid ring compressors [11] and vacuum pumps [12]. It has been reported that substituting water with an ionic liquid in a liquid ring vacuum pump decreased the vacuum pressure by seven times [12]. I.e. it improved the efficiency of the pump considerably. Furthermore, a suitable ionic liquid has also been used as lubrication oil in a screw oxygen compressor [13].

Moreover, the lower compressibility of ionic liquids as compared to the mineral oils and water makes them good candidates for replacement of hydraulic oil in high pressure generating pumps. A remarkable 10 to $30 \%$ improvement of the volumetric efficiency in a diaphragm pump was reported when hydraulic oil was substituted with an ionic liquid, for the first time [12].

Another possibility is to replace the solid piston in a conventional positive displacement compressor by an ionic liquid [12,14]. This type of compressor is sometimes used for compressing pure hydrogen at hydrogen stations [14]. Replacing the solid piston with an ionic liquid in a reciprocating compressor will solve many technical problems which most of the conventional compressors face at present, such as the need for numerous moving parts and complicated sealing systems. In addition, the geometry will be more flexible and the liquid piston can penetrate in non-cylindrical working chambers. Such advantages could lead to more efficient and cheaper compressors with longer life time [14]. 
Additionally, due to direct contact between the ionic liquid and the gas, an optimized geometry might make it possible to extract heat from the gas during the compression procedure [15].

In all the above cases corrosion is a very important factor in selecting an appropriate combination of ionic liquid and construction materials. Corrosion of components which are in contact with the ionic liquid is of course highly undesirable since it can cause serious problems such as reduced efficiency, reduced strength, contamination by the corrosion products, and costly maintenance including shut down of the entire production line. Therefore, it is essential to evaluate the corrosivity of the materials in contact with ionic liquids under relevant conditions.

The corrosion behavior of carbon steel, austenitic stainless steel, nickel-based alloy C22, copper, brass, and aluminum alloy (AlMg $)$ in seven different imidazolium- and ammonium-based ionic liquids by the rotating cage method was evaluated [16]. It was shown in the study that stainless steel type 304 had the highest resistance to erosion corrosion at ambient and higher temperatures, while copper and brass suffered from severe corrosion problems [16]. In another study, very low corrosion current densities of several metals and metal alloys (copper, nickel, AISI 1018 steel, brass, Inconel 600) in 1-butyl3methyl-imidazolium bis (trifluoromethanesulfonyl) imide were measured, at room temperature, based on electrochemical and gravimetric techniques, using potentiodynamic and Tafel curves [17]. Also, the corrosion behavior of carbon steel alloy (1018) in several imidazolium-based ionic liquids at $25{ }^{\circ} \mathrm{C}$ has been studied based on potentiodynamic polarization [18]. The results demonstrated a very low corrosion rate. The main objective of the two previous studies ([17] and [18]) was to evaluate the corrosion behavior of appropriate ionic liquids in contact with vessels and pipes applicable in solar power plants. Another study indicated that nickel had the highest corrosion resistance in several imidazolium-based ionic liquids with different anions, whereas copper, carbon steel and aluminum showed severe corrosion [19]. They also proved that the anions play a more important role in governing ionic liquid corrosivity towards materials than the cation.

The application of ionic liquid in the pneumatic and the hydraulic technologies is quite new, and to the authors' knowledge, so far only one study has been conducted in this field. The corrosion effect of several ionic liquids as lubrication oil in an oxygen screw compressor with rotating cage was also investigated in [13]. However, no information on the liquids was given and it was only mentioned that stainless steel was very stable. The aim of this study is to investigate the corrosion behavior of different construction materials in five ionic liquids selected as operating fluids in an ionic liquid hydrogen compressor. The ionic liquids were selected based on certain criteria such as high thermal and chemical stability, low compressibility and hydrogen solubility, appropriate viscosity, and good lubricating behavior. The three selected ionic liquids with significantly lower viscosity than the other two (shown in Table 1) can be used as liquid piston instead of a solid piston of conventional reciprocating compressors. While the other two ionic liquids might be used in hydrogen compressors, pumps and similar applications where good lubricating properties are more important. 


\section{Experimental}

103

104

105

106

107

108

109

110

111

112

(a)<smiles>CCn1cc[n+](C)c1</smiles>

(b)

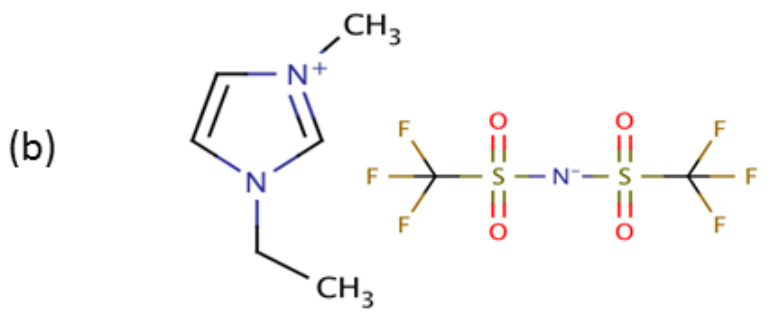

(c)

\subsection{Materials}

1-ethyl-3-methylimidazolium triflate ([EMIM] $\left[\mathrm{CF}_{3} \mathrm{SO}_{3}\right]$ ) ionic liquids tested.
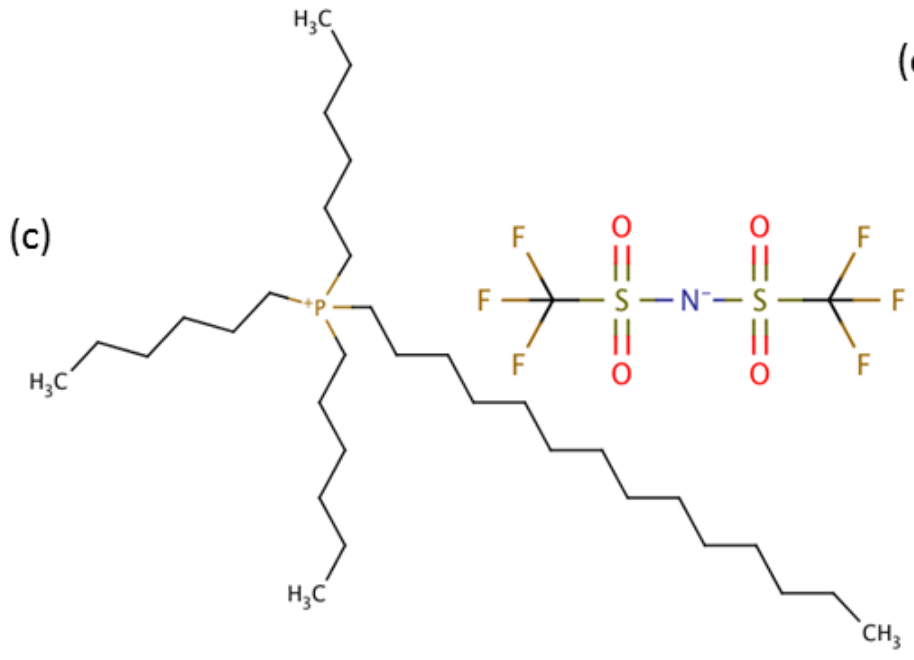

Five ionic liquids (provided by Iolitec [20]) were tested. These five ionic liquids were:

1-ethyl-3-methylimidazolium bis (trifluoromethylsulfonyl) imide ([EMIM][ $\left.\mathrm{Tf}_{2} \mathrm{~N}\right]$ )

trihexyltetradecylphosphonium bis (trifluoromethylsulfonyl) imide ([ $\left.\left.\mathrm{P}_{66614}\right]\left[\mathrm{Tf}_{2} \mathrm{~N}\right]\right)$

butyltrimethylammonium bis (trifluoromethylsulfonyl) imide $\left(\left[\mathrm{N}_{1114}\right]\left[\mathrm{Tf}_{2} \mathrm{~N}\right]\right)$

methyltrioctylammonium bis (trifluoromethylsulfonyl) imide $\left(\left[\mathrm{N}_{1888}\right]\left[\mathrm{Tf}_{2} \mathrm{~N}\right]\right)$

All liquids were of $98 \%$ purity according to the supplier. Figure 1 shows the chemical structure of the

(e)<smiles>CCCC[N+](C)(C)C</smiles>

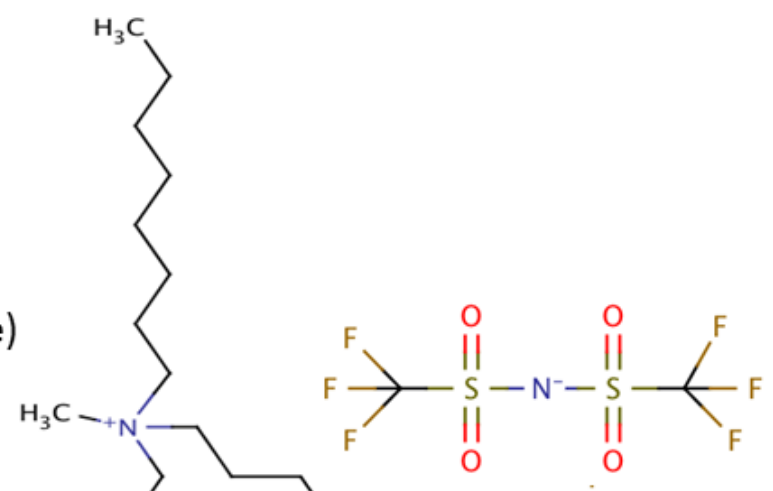

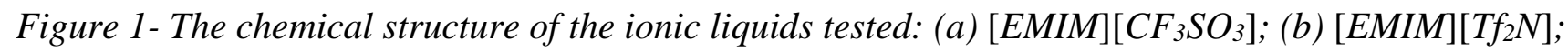
(C) $\left[P_{66614}\right]\left[T f_{2} N\right]$; (d) $\left[N_{1114}\right]\left[T f_{2} N\right]$; (e) $\left[N_{1888}\right]\left[T f_{2} N\right]$ 
122

The density, dynamic and kinematic viscosity of the ionic liquids tested, provided by the manufacturer [20] at $25^{\circ} \mathrm{C}$ and atmospheric pressure, are given in Table 1.

Table 1 - The density, dynamic and kinematic viscosity of the tested ionic liquids at $25^{\circ} \mathrm{C}$ and atmospheric pressure (provided by the manufacturer [20])

\begin{tabular}{cccc}
\hline lonic liquids & Density $(\mathrm{g} / \mathrm{ml})$ & Dynamic viscosity $(\mathbf{c p})$ & Kinematic viscosity $(\mathrm{cSt})$ \\
\hline$[\mathrm{EMIM}]\left[\mathrm{CF}_{3} \mathrm{SO}_{3}\right]$ & 1.38 & 40 & 28.99 \\
{$[\mathrm{EMIM}]\left[\mathrm{Tf}_{2} \mathbf{N}\right]$} & 1.52 & 32 & 21.05 \\
{$\left[\mathrm{P}_{66614}\right]\left[\mathrm{Tf}_{2} \mathrm{~N}\right]$} & 1.06 & 304 & 286.79 \\
{$\left[\mathrm{~N}_{1114}\right]\left[\mathrm{Tf}_{2} \mathbf{N}\right]$} & 1.39 & 99 & 71.22 \\
{$\left[\mathrm{~N}_{1888}\right]\left[\mathrm{Tf}_{2} \mathbf{N}\right]$} & 1.15 & 530 & 460.87 \\
\hline
\end{tabular}

The austenitic stainless steels tested were AISI 316L, AISI 321, AISI 347 and nickel-based alloys Inconel ${ }^{\circledR} 625$ and Hastelloy ${ }^{\circledR}$ C-276, all as wires provided by Sigma Aerospace Metals LLC [21]. Table 2 presents the typical chemical composition of stainless steels and nickel-based alloys investigated in this study.

Table 2 - Chemical composition of the alloys

\begin{tabular}{|c|c|c|c|c|c|c|c|c|c|c|c|c|c|}
\hline \multicolumn{14}{|c|}{ Elements, weight $\%$} \\
\hline Alloy type & $\mathbf{N i}$ & Co & $\mathrm{Cr}$ & Mo & $\mathbf{w}$ & $\mathrm{Fe}$ & Si & Mn & C & Al & $\mathrm{Ti}$ & Other & $\mathrm{Nb}+\mathrm{Ta}$ \\
\hline AISI 316L & $10-13$ & - & $16.5-18.5$ & $2-2.5$ & - & Bal. & 1.0 & 2.0 & 0.03 & - & - & $\begin{array}{c}\mathrm{N} \text { Less } \\
0.11\end{array}$ & - \\
\hline AISI 321 & $9-12$ & - & $17-19$ & - & - & Bal. & 1.0 & 2.0 & 0.08 & - & $0.4-0.7$ & - & - \\
\hline AISI 347 & $9-13$ & - & $17-19$ & - & - & Bal. & 1.0 & 2.0 & 0.08 & - & - & - & 0.8 \\
\hline $\begin{array}{c}\text { Inconel }^{\circledR} \\
625\end{array}$ & 62 & 1.0 & 21.5 & 9.0 & - & 5.0 & 0.5 & 0.5 & 0.1 & 0.4 & 0.4 & - & 3.5 \\
\hline $\begin{array}{c}\text { Hastelloy }^{\circledR} \\
\text { C-276 }\end{array}$ & 57 & 2.5 & 15.5 & 16 & 3.75 & 5.5 & 0.08 & 1.0 & 0.02 & - & - & V 0.35 & - \\
\hline
\end{tabular}

130 For the reference electrode compartment, $\mathrm{Ag}_{2} \mathrm{SO}_{4}$ with purity of 99.9\% (provided by Heraeus [22]) was 131 used.

\subsection{Electrode preparation}

133 The working electrodes were sealed to determine the surface area of the electrodes. Alumina tubes with 134 inner and outer diameters of 2 and $4 \mathrm{~mm}$ respectively, were used for preparing working electrodes of 135 the alloys. A coating paste, CC180W, provided by CeProTec [23], was used for sealing the electrodes 136 inside the tubes, and fixing the area, exposed to the electrolyte. The diameter of the wires varied 137 between 0.8 to $1 \mathrm{~mm}$ and the geometrical working electrode area of all the alloys tested, was in the 
138 range of 8 to $20 \mathrm{~mm}^{2}$ (see Figure A1 in the appendix which presents one of the working electrodes 139 tested in this study).

140 A platinum wire of $0.4 \mathrm{~mm}$ in diameter provided by Dansk Aedelmetal A/S [24] served as a counter 141 electrode. A silver wire of $0.5 \mathrm{~mm}$ in diameter, provided by Dansk Aedelmetal A/S [24], located in the 142 reference compartment of the Pyrex cell served as a reference electrode. The ionic liquid $\left[\mathrm{N}_{1114}\right]\left[\mathrm{Tf}_{2} \mathrm{~N}\right]$ 143 saturated with $\mathrm{Ag}_{2} \mathrm{SO}_{4}$ was used as electrolyte for the reference electrode compartment in all the 144 experiments in this study. Reliability of this reference electrode has been previously reported elsewhere $145[25,26]$. At room temperature, the potential of the $\mathrm{Ag} / \mathrm{Ag}_{2} \mathrm{SO}_{4}$ electrode is about $0.7 \mathrm{~V}$ more positive 146 than of the standard hydrogen electrode [27]. Both platinum and silver wires were shaped to a spiral 147 form to ensure high surface area.

\section{2.3. Electrochemical Characterization}

149 The electrochemical cell shown in Figure 2 was specially designed for the corrosion studies at room 150 temperature $\left(23^{\circ} \mathrm{C}\right)$. A porous frit (Position 7 in Figure 2) separated the working and the reference 151 electrode compartments of the electrochemical cell. The counter electrode was placed in the same 152 compartment where the working electrode was located. The temperature inside the cell was measured 153 by a chromel-alumel PFA coated thermocouple, provided by Omega [28] and located in the same 154 compartment as the working electrode.

155 Steady-state cyclic voltammetry was performed at $23^{\circ} \mathrm{C}$ under atmospheric pressure, using a 156 potentiostat model VersaSTAT 3 with VersaStudio software by Princeton Applied Research [29]. After 157 establishing the open-circuit potential, polarization with a scan rate of $5 \mathrm{mV} / \mathrm{s}$ was initiated to get a 158 steady state response (a cyclic voltametric curve for stainless steel alloy AISI 316L in [EMIM][Tf $2 \mathrm{~N}$ ] 159 with scan rate of $5 \mathrm{mV} / \mathrm{s}$ were shown in Figure A2 in the appendix). The potential window was $2 \mathrm{~V}$, 160 starting at a potential of $-1 \mathrm{~V}$ below the reference electrode potential and going up to $1 \mathrm{~V}$ above the 161 reference electrode potential. 


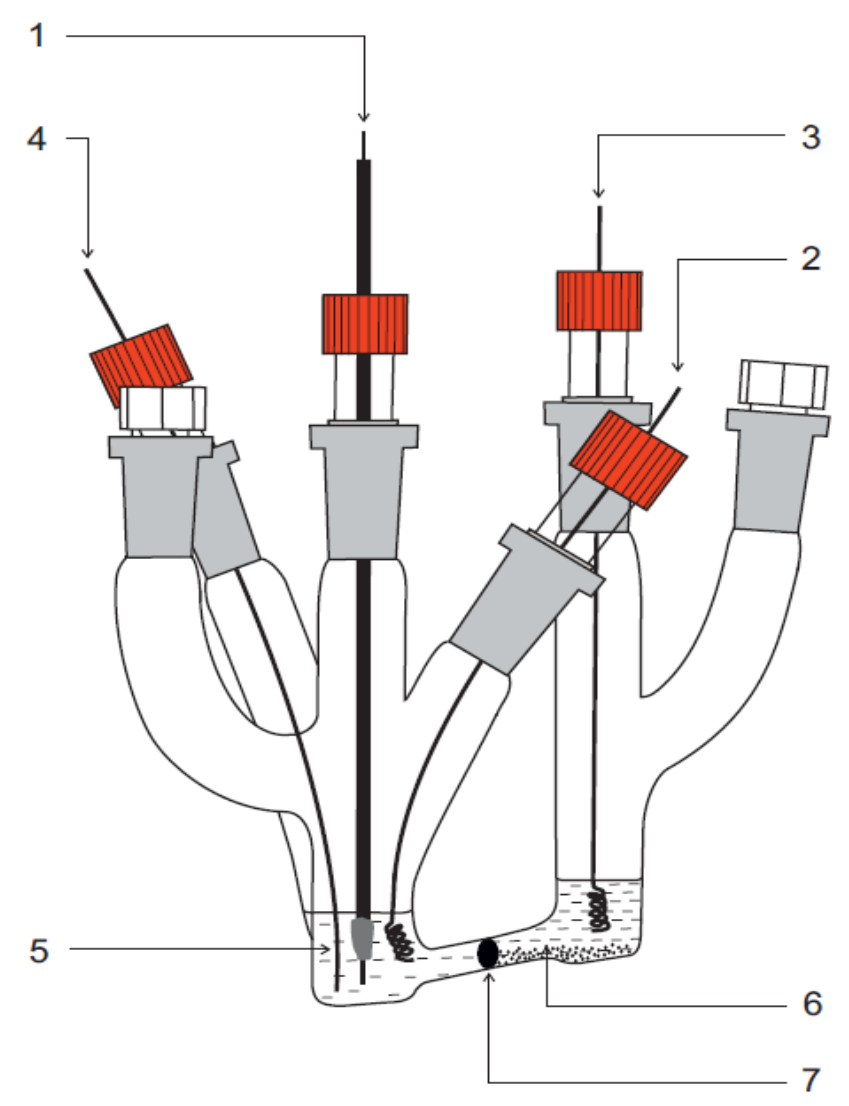

Figure 2- The electrochemical cell: (1) Working electrode; (2) Counter electrode (Pt wire); (3) Reference electrode (Ag wire); (4) Thermocouple; (5) Electrolyte (ionic liquids); (6) Saturated $\mathrm{Ag}_{2} \mathrm{SO}_{4}$ ;(7) porous frit

\section{Results and discussion}

167 Figures 3-7 present Tafel plots for stainless steels and nickel-based alloys in [EMIM] $\left[\mathrm{CF}_{3} \mathrm{SO}_{3}\right]$, 168 [EMIM] $\left[\mathrm{Tf}_{2} \mathrm{~N}\right],\left[\mathrm{P}_{66614}\right]\left[\mathrm{Tf}_{2} \mathrm{~N}\right],\left[\mathrm{N}_{1114}\right]\left[\mathrm{Tf}_{2} \mathrm{~N}\right]$, and $\left[\mathrm{N}_{1888}\right]\left[\mathrm{Tf}_{2} \mathrm{~N}\right]$, respectively. The cyclic Tafel 169 voltammograms can provide valuable information regarding the possible corrosion mechanisms [30]. 170 Figures 3-7 indicate that for all the alloys tested a passivation layer is formed quite easily. By changing 171 the direction of the polarization from anodic to cathodic, the voltammetric curves, in high anodic 172 region close to $1 \mathrm{~V}$ vs. the reference electrode, showed a decrease of the current value at the reversed 173 scan. This fact can be explained by passivation of the electrode with the metal oxide layer [24]. 


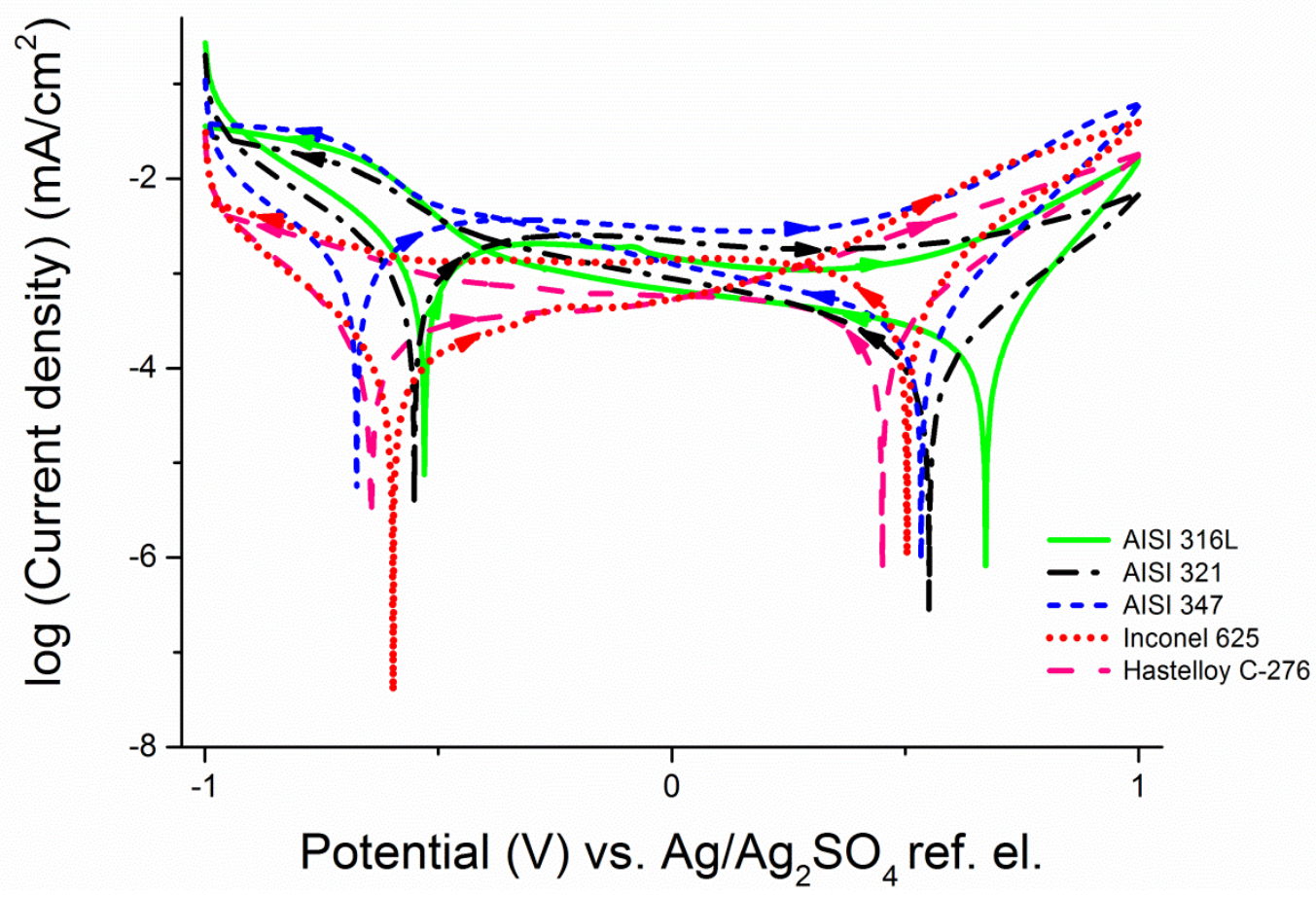

Figure 3 - Tafel plot for the alloys tested in [EMIM] $\left[\mathrm{CF}_{3} \mathrm{SO}_{3}\right]$ at $23^{\circ} \mathrm{C}$

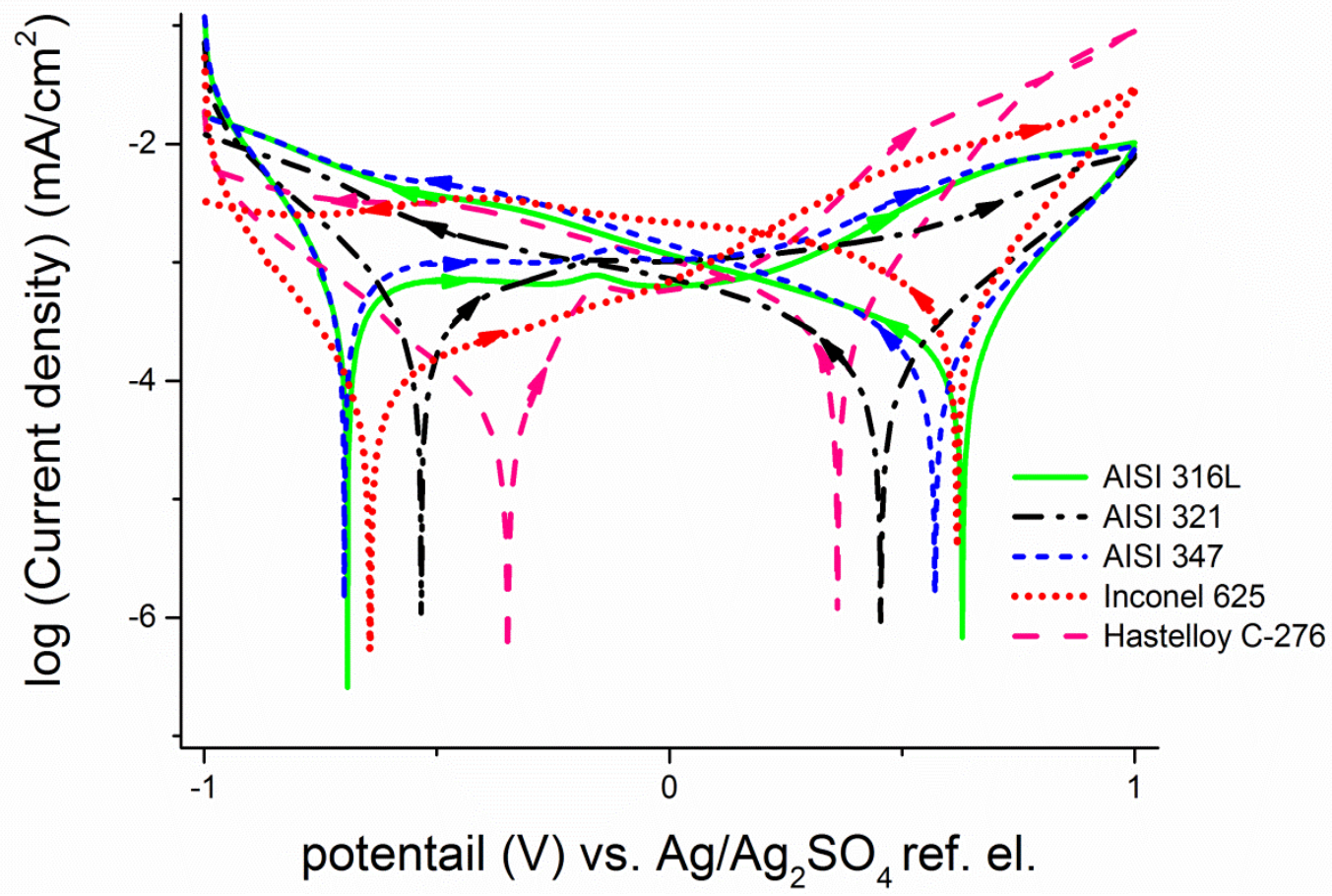

Figure 4- Tafel plot for the alloys tested in [EMIM] $\left[\mathrm{Tf} f_{2} \mathrm{~N}\right]$ at $23^{\circ} \mathrm{C}$ 


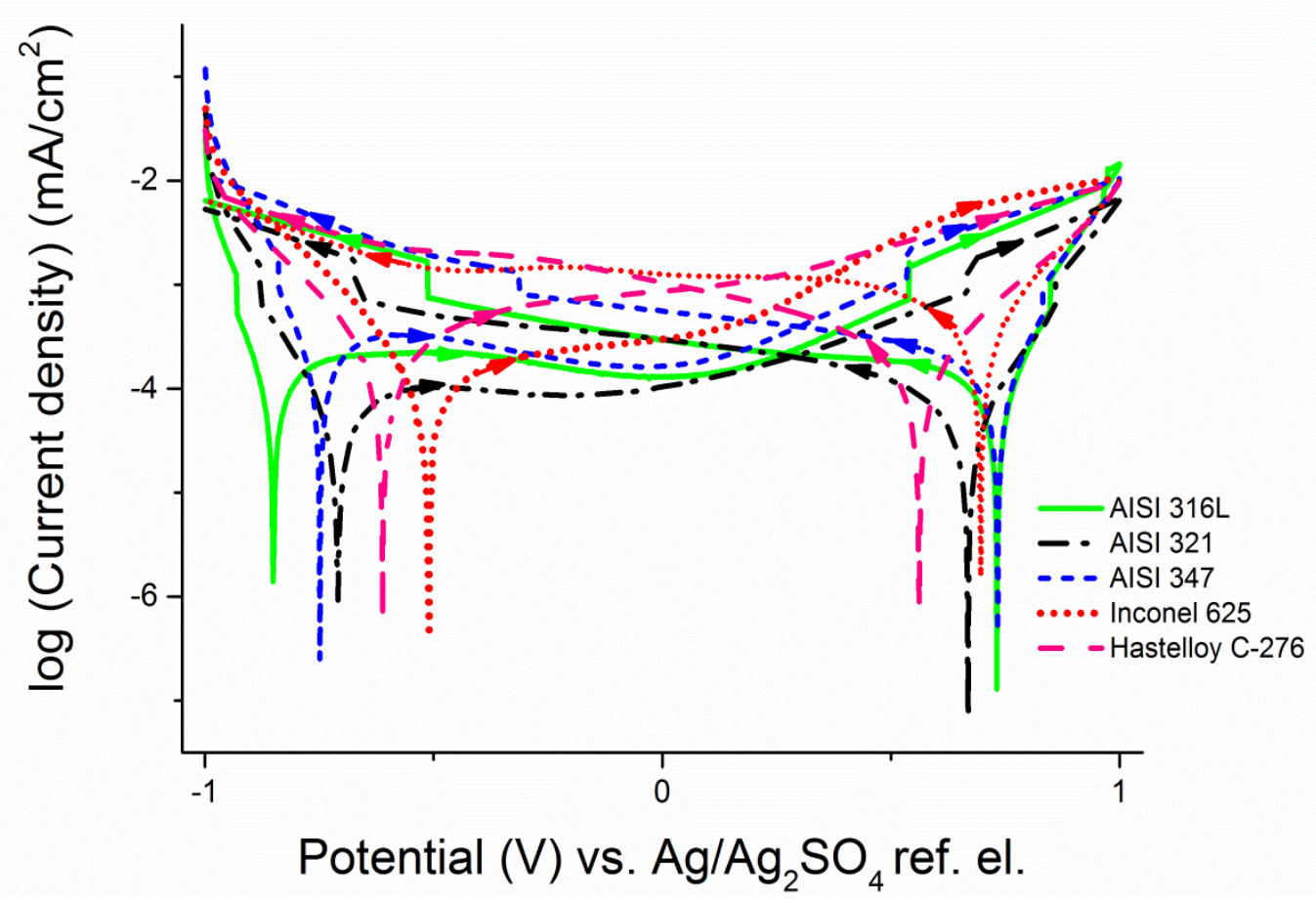

Figure 5- Tafel plot for the alloys tested in $\left[\mathrm{P}_{66614}\right]\left[\mathrm{Tf} f_{2} \mathrm{~N}\right]$ at $23^{\circ} \mathrm{C}$

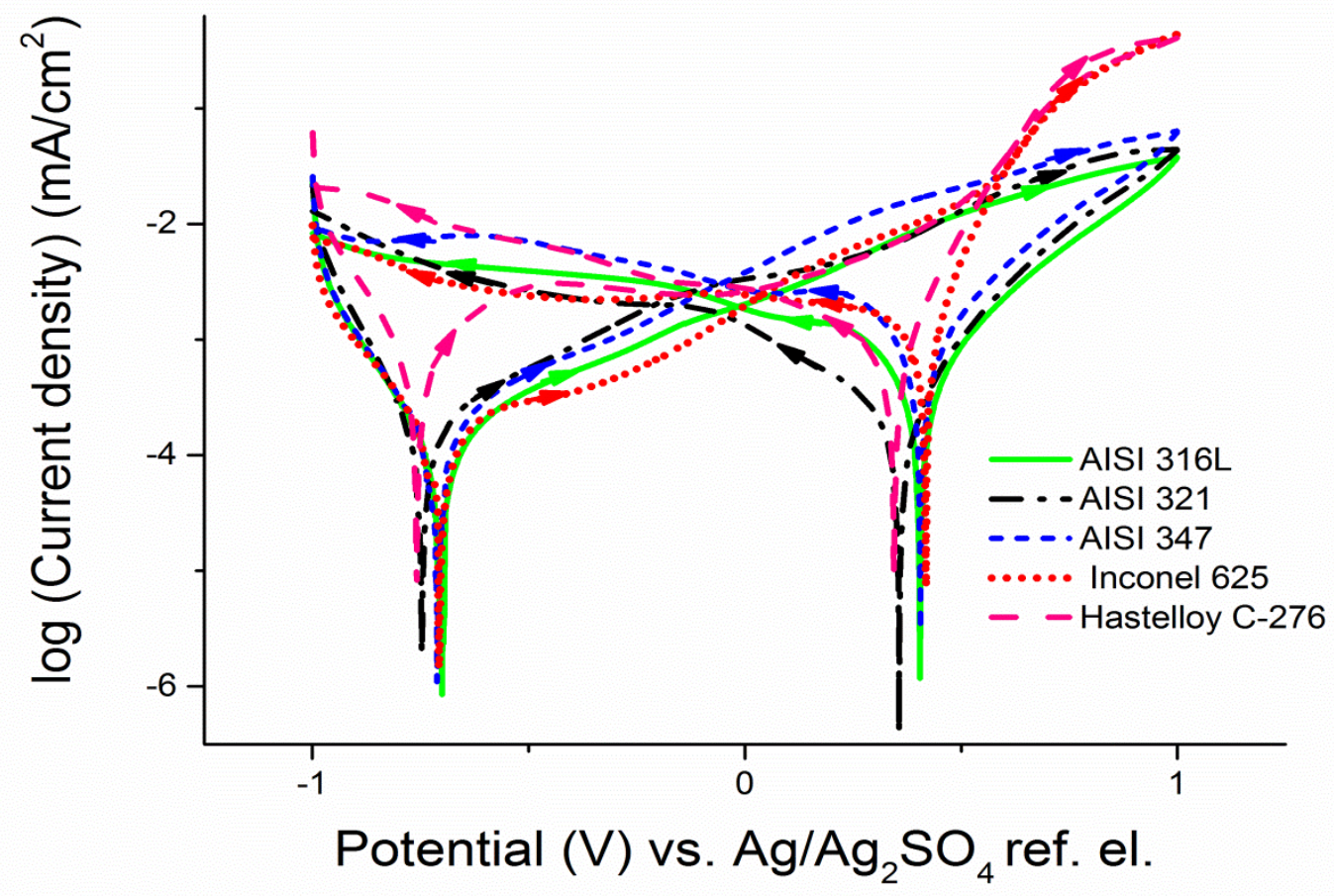

Figure 6 - Tafel plot for the alloys tested in $\left[\mathrm{N}_{1114}\right]\left[\mathrm{Tf}_{2} \mathrm{~N}\right]$ at $23^{\circ} \mathrm{C}$ 


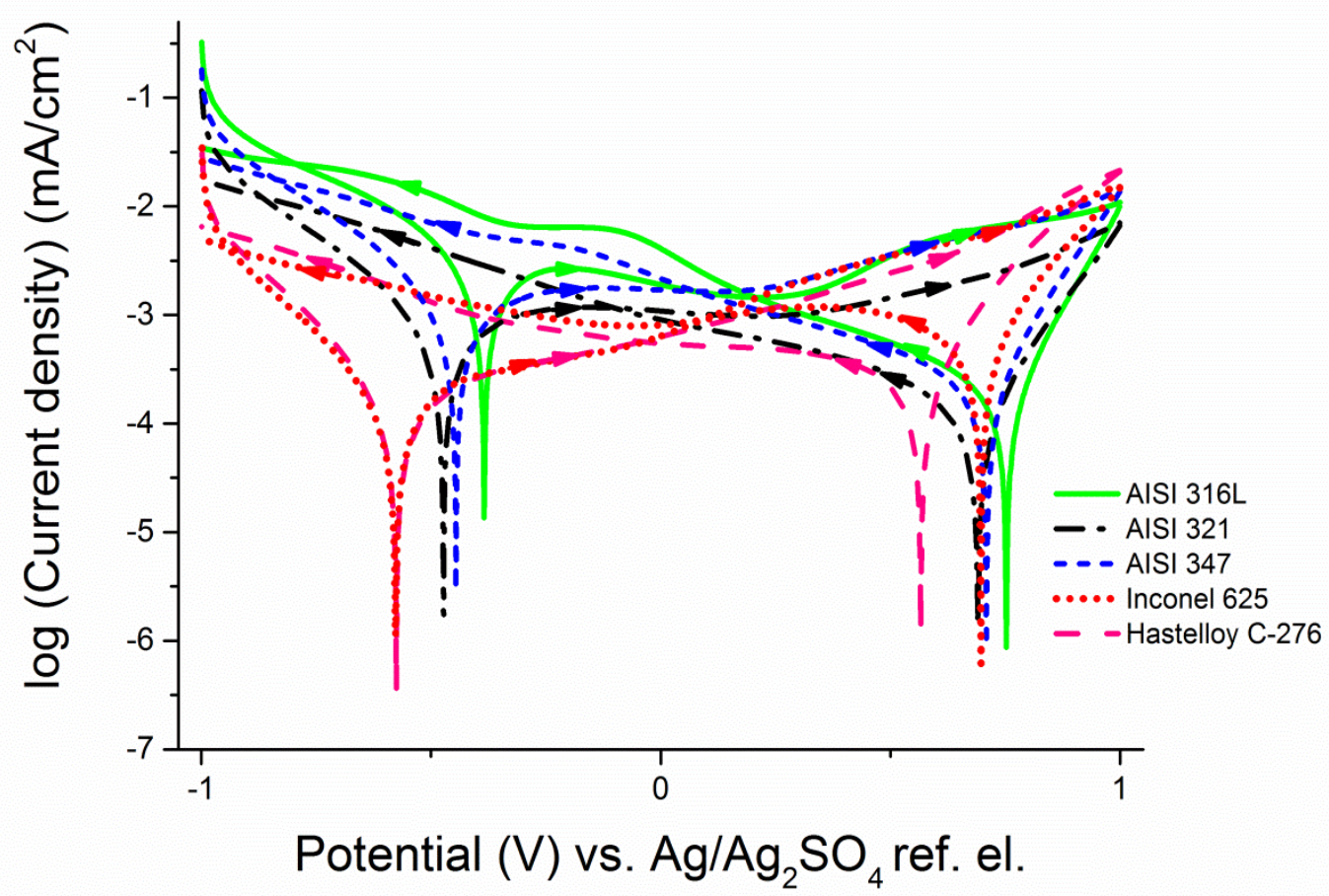

184

\begin{tabular}{|c|c|c|c|c|c|}
\hline \multicolumn{6}{|c|}{$\mathrm{i}_{\text {corr }}\left(10^{-5} \mathrm{~mA} / \mathrm{cm}^{2}\right)$} \\
\hline & {$[\mathrm{EMIM}]\left[\mathrm{CF}_{3} \mathrm{SO}_{3}\right]$} & {$[E M I M]\left[\mathrm{Tf}_{2} \mathrm{~N}\right]$} & {$\left[\mathrm{P}_{66614}\right]\left[\mathrm{Tf}_{2} \mathrm{~N}\right]$} & {$\left[\mathrm{N}_{1114}\right]\left[\mathrm{Tf}_{2} \mathrm{~N}\right]$} & {$\left[\mathrm{N}_{1888}\right]\left[\mathrm{Tf}_{2} \mathrm{~N}\right]$} \\
\hline AISI 316L & 0.8 & 1.6 & 0.8 & 4 & 1.8 \\
\hline AISI 321 & 0.8 & 1.1 & 0.8 & 3.2 & 0.8 \\
\hline AISI 347 & 2.5 & 1.3 & 1.3 & 8 & 2.5 \\
\hline Inconel ${ }^{\circledR} 625$ & 5 & 4 & 3.2 & 16 & 5 \\
\hline Hastelloy ${ }^{\circledR}$ C-276 & 1.8 & 2 & 1 & 10 & 2 \\
\hline
\end{tabular}

Figure 7 - Tafel plot for the alloys tested in $\left[N_{1888}\right]\left[T f_{2} N\right]$ at $23^{\circ} \mathrm{C}$

Furthermore, valuable data such as corrosion current density ( $\mathrm{i}_{\text {corr }}$ ), corrosion potential of the electrode ( $E_{\text {corr }}$ ), and electrochemical stability window (potential window), can be obtained from the Tafel plots. A schematic view of Tafel plot for stainless steel alloy AISI 316L in [EMIM] $\mathrm{Tf}_{2} \mathrm{~N}$ ] were shown in the appendix, Figure A3). Table 3 shows the estimated corrosion current densities in the five mentioned electrolytes, obtained from Figures 3-7. The corrosion current density can be estimated from the intersection point of the vertical line through $\mathrm{E}_{\mathrm{corr}}$ and the extrapolated linear portions of the anodic and cathodic polarizations $[30,31]$.

Table 3 - Corrosion current densities for the stainless steels and nickel-based alloys in the ionic liquids tested 
196 It can be seen from Table 3 that the corrosion rate of the materials studied here in the mentioned ionic 197 liquids is very small even in the worst case $\left(16 \times 10^{-5} \mathrm{~mA} / \mathrm{cm}^{2}\right)$. Therefore, all the alloys can safely be used for construction of the components in direct contact with the ionic liquids tested. Since the estimated corrosion current densities for all the alloys in each electrolyte are comparable, parameters such as corrosion potential and electrochemical stability window can be utilized for detailed comparison of the corrosion resistance.

Table 4 presents the corrosion potentials of the alloys tested, obtained from Figures 3-7. It can be assumed that the corrosion potentials (current drop at positive potentials) in the Tafel voltammograms, on Figures 3-7, correspond to the dissolution of the anodically polarized alloys. The cathodic processes (current drop at negative potentials) could be reduction of oxygen or electrolyte, however further study in chemistry and electrochemistry of the tested ionic liquids is required for detailed understanding of these processes. The lower corrosion rate is expected for the more positive values of the corrosion potentials, as has been observed in an earlier study [32].

Table 4 - Corrosion potentials of the stainless steels and nickel-based alloys in the ionic liquids tested

\begin{tabular}{cccccc}
\hline \multicolumn{5}{c}{$\mathrm{E}_{\text {corr, }} \mathrm{mV}\left(\mathrm{vs} . \mathrm{Ag} / \mathrm{Ag}_{2} \mathrm{SO}_{4}\right)$} \\
\hline AISI 316L & 671 & 629 & 731 & 404 & 752 \\
AISI 321 & 551 & 454 & 669 & 356 & 689 \\
AISI 347 & 533 & 570 & 733 & 406 & 708 \\
Inconel $^{\circledR} 625$ & 504 & 619 & 696 & 418 & 697 \\
Hastelloy $^{\circledR} \mathrm{C}-276$ & 451 & 361 & 561 & 345 & 566 \\
\hline
\end{tabular}

211

212

213

214

215

216

Table 5 presents the electrochemical stability windows (potential windows) obtained on the stainless steels and nickel-based electrodes in the tested ionic liquid electrolytes, derived from Figures 3-7. The electrochemical stability window is calculated as a difference between the potential of the cathodic and anodic limiting reactions.

Table 5 - Electrochemical stability windows obtained on the stainless steels and nickel-based alloys in the ionic liquids tested

Potential window, $\mathrm{mV}$

\begin{tabular}{cccccc}
\hline & {$\left[\mathrm{EMIM}\left[\mathrm{CF}_{\mathbf{3}} \mathrm{SO}_{\mathbf{3}}\right]\right.$} & {$[\mathrm{EMIM}]\left[\mathrm{Tf}_{\mathbf{2}} \mathbf{N}\right]$} & {$\left[\mathbf{P}_{66614}\right]\left[\mathrm{Tf}_{\mathbf{2}} \mathbf{N}\right]$} & {$\left[\mathbf{N}_{\mathbf{1 1 1 4}}\right]\left[\mathrm{Tf}_{\mathbf{2}} \mathbf{N}\right]$} & {$\left[\mathbf{N}_{\mathbf{1 8 8 8}}\right]\left[\mathrm{Tf}_{\mathbf{2}} \mathbf{N}\right]$} \\
AISI 316L & 1201 & 1321 & 1582 & 1104 & 1137 \\
AISI 321 & 1103 & 988 & 1440 & 1103 & 1162 \\
AISI 347 & 1208 & 1269 & 1482 & 1117 & 1154 \\
Inconel $^{\circledR} 625$ & 1101 & 1263 & 1206 & 1125 & 1275 \\
\hline
\end{tabular}




\begin{tabular}{llllll}
\hline Hastelloy $^{\circledR}$ C-276 & 1094 & 709 & 1172 & 1104 & 1142 \\
\hline
\end{tabular}

218

219

220

221

222

223

224

225

226

227

228

229

230

231

232

233

234

235

236

237

238

239

240

241

242

243

244

245

246

247

248

249

250

As it can be seen from Tables 4 and 5, and corresponding Figures 3-7, between the three stainless steel alloys tested, AISI 316L and AISI 347, showed higher corrosion resistance than AISI 321 in all the ionic liquids tested.

The high corrosion resistance of AISI 316L can be explained by 2-2.5 wt. \% of molybdenum in the structure of AISI 316L. However, the highest contents of molybdenum are only possible in high nickel alloys, adding a small amount of molybdenum, even one or two percent, to stainless steels can considerably increase the corrosion resistance of these alloys [33,34]. Molybdenum decreases the corrosion rate by stabilizing the previously formed passive films [35]. In addition, 0.8 wt. \% of niobium and tantalum in the structure of AISI 347, and its role in the formation of oxide layer can explain the high corrosion resistance of AISI 347 [36]. The lowest corrosion resistance of AISI 321 indicated that molybdenum, tantalum, and niobium played more important roles in increasing the corrosion resistance of the alloys than titanium.

Comparing the corrosion resistance of the nickel-based alloys (nickel content above 55 wt. \%) with stainless steel alloys (nickel content 9-13 wt. \%) in all the ionic liquids tested (Figure 3-7, and Tables 4 and 5) showed that high nickel concentration did not have a considerable effect on corrosion rate.

Hastelloy ${ }^{\circledR}$ C-276 showed the poorest corrosion resistance in [EMIM] $\left[\mathrm{CF}_{3} \mathrm{SO}_{3}\right]$, [EMIM][Tf $2 \mathrm{~N}$, $\left[\mathrm{P}_{66614}\right]\left[\mathrm{Tf}_{2} \mathrm{~N}\right],\left[\mathrm{N}_{1114}\right]\left[\mathrm{Tf}_{2} \mathrm{~N}\right]$, and $\left[\mathrm{N}_{1888}\right]\left[\mathrm{Tf}_{2} \mathrm{~N}\right]$. Thus Hastelloy ${ }^{\circledR} \mathrm{C}-276$ had the highest corrosion rate of all the alloys in all the electrolytes tested. This could be due to a lack of niobium and tantalum in the structure of Hastelloy ${ }^{\circledR}$ C-276 (comparison with Inconel ${ }^{\circledR}$ 625), since small amounts of niobium and tantalum could increase the stability of the passivation layer [36,37].

In general, as mentioned above, the corrosion current densities for all the tested alloys, in all the ionic liquids were quite small. Hence, all the alloys can safely be used for construction of the components in direct contact with the tested ionic liquids, in an ionic liquid hydrogen compressor. For most manufacturers, price is another important factor to consider during selection of the appropriate materials. Consequently, among all the alloys tested, AISI 316L is the cheapest with high corrosion resistance in all the ionic liquids studied in this work, and is recommended as one of the most promising candidates. It should also be considered that in ionic liquid hydrogen compressor, apart from corrosion rate and price, hydrogen embrittlement is another important factor to be taken into account; it has been reported that austenitic stainless steel type 316L has very high resistance to hydrogen embrittlement [38-40].

Figure 8 shows the estimated range of corrosion current densities for AISI 316L, in the five electrolytes tested. It can be seen from Figure 8 that the corrosion rate of AISI 316L, even in the worst case (for $\left.\left[\mathrm{N}_{1114}\right]\left[\mathrm{Tf}_{2} \mathrm{~N}\right]\right)$, is very small and is comparable to the corrosion rate value for one of the most corrosion 
stable metals in an aggressive solution of hot phosphoric acid, tantalum ( $\mathrm{i}_{\text {corr }}=31.5 \times 10^{-5} \mathrm{~mA} / \mathrm{cm}^{2}$, equals to corrosion rate $<0.001 \mathrm{~mm} /$ year), which have been earlier reported [32]. The two imidazoliumbased ionic liquids, [EMIM][Tf $2 \mathrm{~N}]$ and $[\mathrm{EMIM}]\left[\mathrm{CF}_{3} \mathrm{SO}_{3}\right]$, with significantly lower viscosity (as seen in Table 1), showed lower corrosion current densities and can be recommended as the best candidates to be used instead of a solid piston of conventional reciprocating compressors in ionic liquid hydrogen compressors.

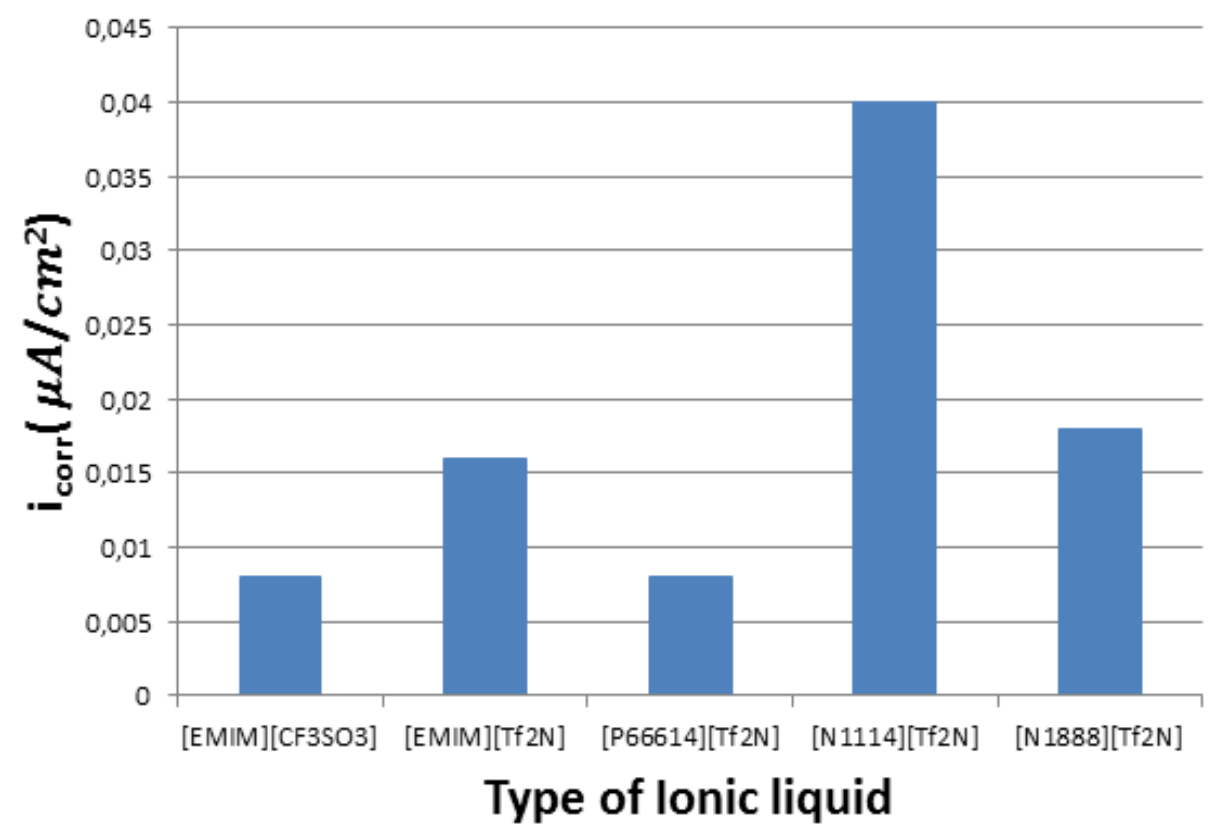

Figure 8 - Measured corrosion current densities for AISI 316L in the ionic liquids tested

\section{Conclusions}

The work was performed on the corrosion resistance study of commercially available stainless steels and nickel-based alloys in five different ionic liquids, which have been selected as possible performance fluids in an ionic liquid hydrogen compressor, at $23{ }^{\circ} \mathrm{C}$, under atmospheric pressure. The results have shown very small corrosion rates of the tested materials in the selected ionic liquids. Consequently, all the alloys tested are safe to use as construction materials for the components which are in direct contact with the ionic liquids studied.

The reduction of current on the reverse voltammetric curves compared to the current of the forward ones, in high anodic region close to $1 \mathrm{~V}$ vs. the reference electrode showed the formation of a passivation layer on almost all the alloys. AISI 316L and AISI 347 showed higher corrosion resistance than AISI 321, in all the ionic liquids tested. Small addition of molybdenum, tantalum, and niobium in the structure of the alloy increased the corrosion stability of the alloy tested in the selected ionic 
liquids. Nickel-based alloy, Hastelloy ${ }^{\circledR}$ C-276 showed the poorest resistance to corrosion in all the ionic liquids tested. Comparison of the corrosion resistance of the nickel-based alloys with stainless steel alloys in all the ionic liquids tested showed that high nickel concentration does not play a significant role on corrosion rate of the alloys tested in the selected ionic liquid electrolytes.

Ultimately, considering the observed corrosion rates, prices, and resistance to hydrogen embrittlement, for all the tested stainless steels and nickel-based alloys, stainless steel AISI 316L is recommended as construction material for all the components which are in direct contact with the studied ionic liquids in an ionic liquid hydrogen compressor. Furthermore, the two imidazolium-based ionic liquids, $[\mathrm{EMIM}]\left[\mathrm{Tf}_{2} \mathrm{~N}\right]$ and $[\mathrm{EMIM}]\left[\mathrm{CF}_{3} \mathrm{SO}_{3}\right]$, with significantly lower viscosity and corrosion current densities for AISI 316L can be recommended for use instead of a solid piston of conventional reciprocating compressors in an ionic liquid hydrogen compressors.

282

283

284

285

286

287

288

289

290

291

292

293

294

295

296

297

298

299

300

301

302

303

304

\section{Acknowledgment}

The authors would like to thank the Innovation Fund Denmark for financial support of the work (grant number DNF93, HyFill-Fast project), Susanne Helmark (DTU Chemistry) for help with graphics, and Jan Patrick Scholer for making the cell by glass blowing.

\section{References}

[1] Endres F, MacFarlane D, Abbott A. Electrodeposition from ionic liquids. Wiley-VCH; 2008.

[2] Ohno H, editor. Electrochemical Aspects of Ionic Liquids, Second Edition. Willey; 2011.

[3] Keskin S, Kayrak-Talay D, Akman U, Hortaçsu Ö. A review of ionic liquids towards supercritical fluid applications. J Supercrit Fluids 2007;43:150-80. doi:10.1016/j.supflu.2007.05.013.

[4] Laali KK. Ionic Liquids in Synthesis. Synthesis (Stuttg) 2003;2003:1752-1752. doi:10.1055/s2003-40869.

[5] Armand M, Endres F, MacFarlane DR, Ohno H, Scrosati B. Ionic-liquid materials for the electrochemical challenges of the future. Nat Mater 2009;8:621-9. doi:10.1038/nmat2448.

[6] Zhou F, Liang Y, Liu W. Ionic liquid lubricants: designed chemistry for engineering applications. Chem Soc Rev 2009;38:2590-9. doi:10.1039/b817899m.

[7] Werner S, Haumann M, Wasserscheid P. Ionic liquids in chemical engineering. Annu Rev Chem Biomol Eng 2010;1:203-30. doi:10.1146/annurev-chembioeng-073009-100915.

[8] Plechkova N V, Seddon KR. Applications of ionic liquids in the chemical industry. Chem Soc Rev 2008;37:123-50. doi:10.1039/b006677j.

[9] Marrucho IM, Branco LC, Rebelo LPN. Ionic liquids in pharmaceutical applications. Annu Rev Chem Biomol Eng 2014;5:527-46. doi:10.1146/annurev-chembioeng-060713-040024.

[10] Schluecker E, Szarvas L, Uerdingen E. New developments in pumps and compressors using 
ionic liquids. ACHEMA World Wide News 2008:5-7.

[11] C. Muller, M. Sesing, M. Fiene, O. Huttenloch ES. Method for operating a liquid ring compressor. Pub. No.: US 2007/02669309, 2011.

[12] C. Hilgers, M. Uerdingen, M. Wanger, P. wasserscheid ES. Processing and/or operating machine comprising an ionic liquid as the operating liquid. Pub. No.: US 2008/0038123 A1, 2008.

[13] Predel T, Schlücker E. Ionic liquids in oxygen compression. Chem Eng Technol 2009;32:11838. doi:10.1002/ceat.200900047.

[14] Report. Linde Technology 2006. http://www.the-lindegroup.com/internet.global.thelindegroup.global/en/images/Linde_Technology_1_2006_EN14_1 0188.pdf.

[15] Arjomand Kermani N, Rokni M. Heat transfer analysis of liquid piston compressor for hydrogen applications. Int J Hydrogen Energy 2015;40:11522-9. doi:10.1016/j.ijhydene.2015.01.098.

[16] Uerdingen M, Treber C, Balser M, Schmitt G, Werner C. Corrosion behaviour of ionic liquids. Green Chem 2005;7:321. doi:10.1039/b419320m.

[17] Perissi I, Bardi U, Caporali S, Lavacchi A. High temperature corrosion properties of ionic liquids. Corros Sci 2006;48:2349-62. doi:10.1016/j.corsci.2006.06.010.

[18] Arenas MF, Reddy RG. Corrosion of steel in ionic liquids. J Min Metall Sect ... 2003;39:81-91. doi:10.2298/JMMB0302081A.

[19] Wang Y, Lee T, Lin J, Chang J, Tseng C. Corrosion properties of metals in dicyanamide-based ionic liquids. Corros Sci 2014;78:81-8. doi:10.1016/j.corsci.2013.09.002.

[20] Iolitec - Ionic Liquids Technologies n.d. http://www.iolitec.de/en/Company/company.html (accessed August 29, 2014).

[21] Sigma Aerospace Metals - Sigma Aerospace Metals, LLC n.d. http://www.sigmaaero.com/ (accessed August 29, 2014).

[22] Heraeus - Precious metals and technology Group n.d. http://www.heraeus.com/en/home.html (accessed September 1, 2014).

[23] Keramische Oberflächenbeschichtung, Coatings und temperaturbeständige Beschichtungen n.d. http://www.ceprotec.de/ (accessed September 1, 2014).

[24] DANSK AEDELMETAL n.d. http://www.dansk.aedelmetal.dk/index.php (accessed September 1, 2014).

[25] Bjerrum N, Petrushina I, Berg R. Electrochemical investigation of the catalytical processes in sulfuric acid production. J Electrochem Soc 1995;142:1805-13.

[26] Petrushina I, Bjerrum N. Electrochemical behavior of molten V2O5-K2S207-KHSO4 systems. ... Electrochem Soc 1997;144:532-9.

[27] Meites L. Handbook of Analytical Chemistry. McGraw Hill; 1963.

[28] OMEGA Engineering Company n.d. http://www.omega.com/ (accessed February 17, 2016).

[29] VersaStudio n.d. http://www.princetonappliedresearch.com/Our-Products/ElectrochemicalSoftware/VersaStudio.aspx (accessed September 1, 2014). 
[30] Trethewey KR, Chamberlain J. Corrosion for students of science and engineering. Longman Scientific \& Technical; 1988.

[31] ASTM International - Annual Book of ASTM Standards 10.05, g3-89. n.d.

[32] Nikiforov AV, Petrushina IM, Christensen E, Tomás-García AL, Bjerrum NJ. Corrosion behaviour of construction materials for high temperature steam electrolysers. Int J Hydrogen Energy 2011;36:111-9. doi:10.1016/j.ijhydene.2010.09.023.

[33] Sugimoto K, Sawada Y. The role of molybdenum additions to austenitic stainless steels in the inhibition of pitting in acid chloride solutions. Corros Sci 1977;17:425-45. doi:10.1016/0010938X(77)90032-4.

[34] Pardo A, Merino MC, Coy AE, Viejo F, Arrabal R, Matykina E. Pitting corrosion behaviour of austenitic stainless steels - combining effects of Mn and Mo additions. Corros Sci 2008;50:1796-806. doi:10.1016/j.corsci.2008.04.005.

[35] Cunat P. Alloying elements in stainless steel and other chromium-containing alloys. Int Chromium Dev Assoc 2004:1-24.

[36] Lyon SB. Corrosion of tantalum and niobium and their alloys. Shreir's Corros 2010:2135-50. doi:10.1016/B978-044452787-5.00102-5.

[37] Smith GD. The effect of niobium on the corrosion resistance of nickel-base alloys. Proc Int Symp Niobium High Temp Appl 2004:23-34.

[38] Marchi CS, Somerday B. Technical reference on hydrogen compatibility of materials. Austenitic Stainl Steels Type 2008;316.

[39] Omura T, Nakamura J. Hydrogen embrittlement of stainless steel. Zairyo-to-Kankyo 2011;60:241-7. doi:10.3323/jcorr.60.241.

[40] Szummer A. Comparison of hydrogen embrittlement of stainless steels and nickel-base alloys. Int J Hydrogen Energy 2002;27:793-800.

\section{Appendix A}




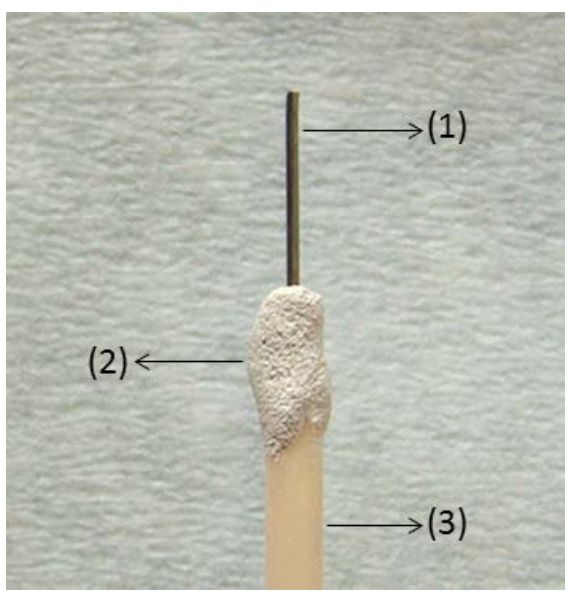

372

373

374
Figure A1-Picture of the working electrode (1) The fixed area of the electrode exposed to the electrolyte; (2) Coating paste (CC180W); (3) Alumina Tube

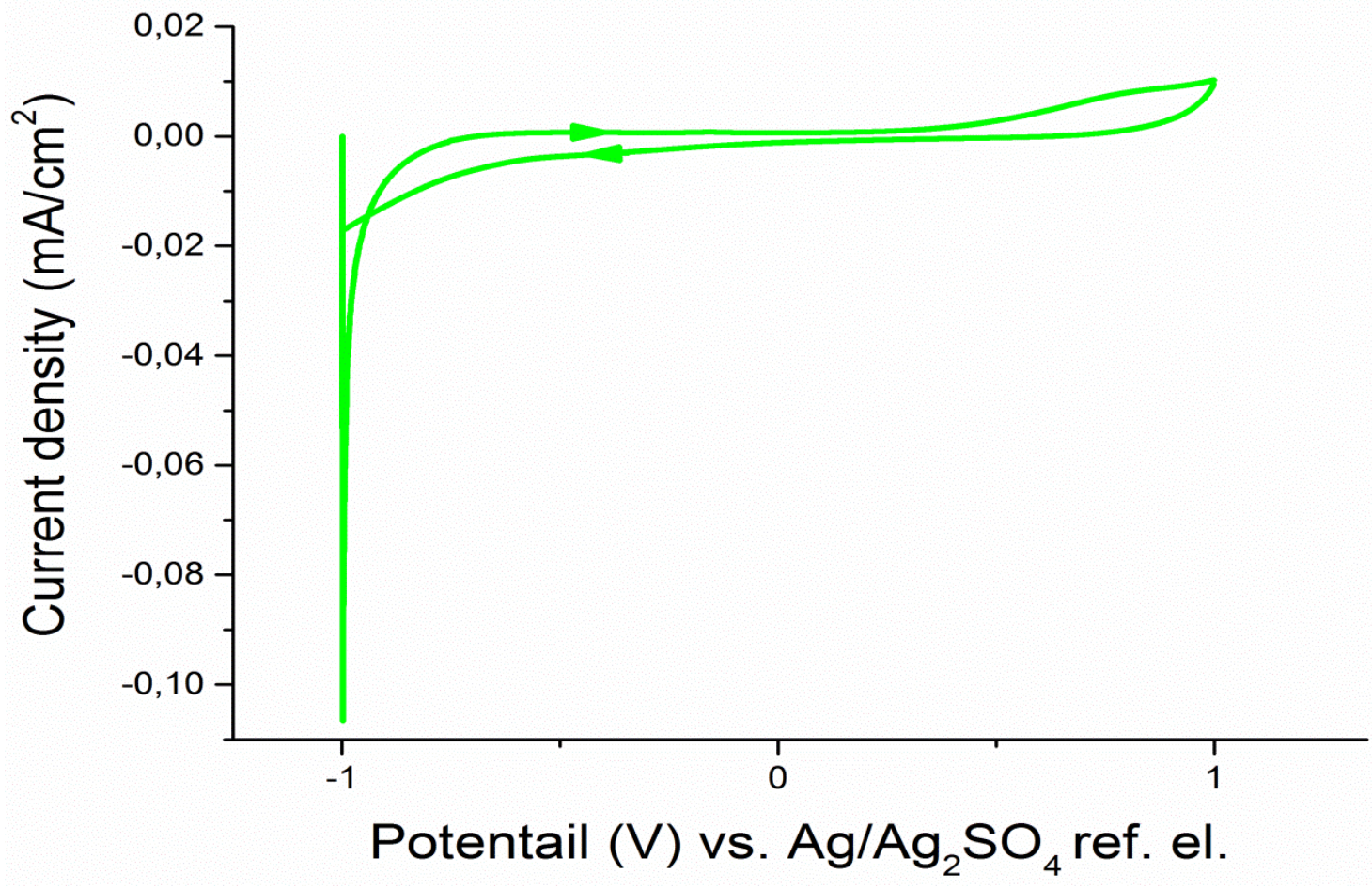

Figure A2 - cyclic voltametric curve for stainless steel alloy AISI 316L in [EMIM] [Tf $\left.{ }_{2} N\right]$ with scan rate of $5 \mathrm{mV} / \mathrm{s}$.

The general overview of the voltametric curve shows a steady state response, as no peaks were observed in the voltametric curve 


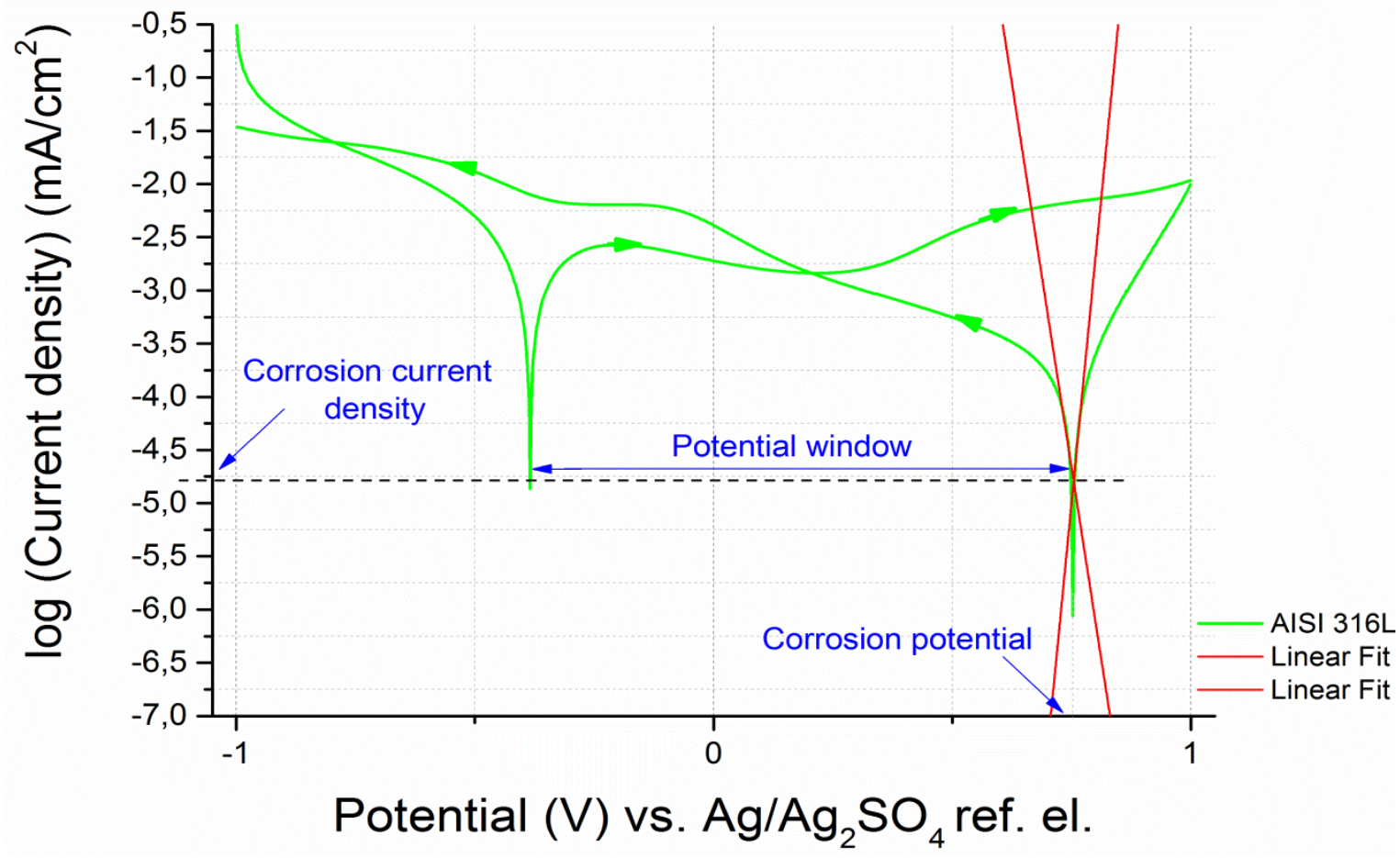

